\title{
Korrespondenzen.
}

\section{Ueber Agglutinine und spezifische Immunkörper im} Gonococcenserum.

Bemerkung zu der in No. 49 der Deutschen medizinischen Wochenschrift erschienenen Pablikation von Dr. Th. Vannod.

Von Dr. R. Müller, Assistenten der Klinik Prof. Finger, und Privatdozenten Dr. M. Oppenheim.

Am 19. Juli 1906 erschien in No. 29 der Wiener klinischen Wochenschrift unter dem Titel: Ueberden Nachweis von Antikörpern im Serum eines an Arthritis gonorrhoica Erkrankten mittels Komplementablenkung unsere Mitteilung, in der wir durch die Komplementablenkung den Nachweis von Antikörpern im Gonorrhoeserum zum ersten Male einwandfrei erbringen.

Im August desselben Jahres bestätigt B ruck in einer in No. 3 dieser Wochenschrift unter dem Titel "Ueber spezifische Immunkörper gegen Gonococcen" publizierten Arbeit unsere Befunde mit folgenden Worten: „Es geht also aus den mitgeteilten Fällen in Uebereinstimmung mit dem Befunde von Müller und Oppenheim hervor, daß es in der Tat zuweilen gelingt, im Blutserum von Menschen, die unter dem Einfluß von Gonococceninfektion stehen, spezifische Immunkörper nachzuweisen.“

In der letzten Nummer dieser Wochenschrift vom 6. Dezember 1906, also fast fünf Monate nach dem Erscheinen unserer Publikation und fast vier Monate nach der Publikation Brucks, nimmt Dr. Th. Vannod in einer unter dem Titel: „Ueber Agglutinine und spezifische Immunkörper im Gonococenserum" für sich und Bruck die Priorität des Nachweises der Antikörper im Gonococcenserum in Anspruch, ohne unserer Publikation auch nur mit einem Worte zu gedenken. Bruck stellt an die Spitze seiner Arbeit unsere Befunde und nimmt wiederholt auf unsere Arbeit bezug. Warum Herr Dr. Th. Vannod es unterläßt, uns zu zitieren, die den Nachweis von Antikörpern im Gonorrhoeserum zuerst erbracht haben, ist uns vollständig unerfindlich.

Es sei uns daher gestattet, hier nochmals den Schlußsatz unserer im Juli 1906 erschienenen Publikation, die Vannod gekannt haben mußte, im Wortlaute zu zitieren: „Die Hemmung der Hämolyse beweist demnach einwandfrei die Gegenwart eines spezifischen Antikörpers im Serum eines an Arthritis gonorrhoica Erkrankten." Wien, am 13. Dezember 1906. 